Georgia State University

ScholarWorks @ Georgia State University

2005

\title{
An Analysis of Indonesia's Transfer System: Recent Performance and Future Prospects
}

Bambang Brodjonegoro

Republic of Indonesia

Jorge Martinez-Vazquez

Georgia State University, jorgemartinez@gsu.edu

Follow this and additional works at: https://scholarworks.gsu.edu/econ_facpub

Part of the Economics Commons

\section{Recommended Citation}

Martinez-Vazquez, Jorge, and Bambang Brodjonegoro. 2005. "An Analysis of Indonesia's Transfer System: Recent Performance and Future Prospects." In Reforming Intergovernmental Fiscal Relations and the Rebuilding of Indonesia: The 'Big Bang' Program and its Economic Consequences, edited by Jorge Martinez-Vazquez, Sri Mulyani Indrawati and James Alm, 159-198. Edward Elgar Publishing.

This Book Chapter is brought to you for free and open access by the Department of Economics at ScholarWorks @ Georgia State University. It has been accepted for inclusion in ECON Publications by an authorized administrator of ScholarWorks @ Georgia State University. For more information, please contact scholarworks@gsu.edu. 


\section{Reforming}

\section{Intergovernmental Fiscal Relations and the Rebuilding of Indonesia}

The 'Big Bang' Program and its Economic Consequences

Edited by

James Alm

Georgia State University, USA

Jorge Martinez-Vazquez

Georgia State University, USA

Sri Mulyani Indrawati

International Monetary Fund, USA

STUDIES IN FISCAL FEDERALISM AND STATE-LOCAL FINANCE

\section{Edward Elgar}

Cheltenham, UK $\bullet$ Northampton, MA, USA 
All rights reserved. No part of this publication may be reproduced, stored in a retrieval system or transmitted in any form or by any means, electronic, mechanical or photocopying, recording, or otherwise without the prior permission of the publisher.

Published by

Edward Elgar Publishing Limited

Glensanda House

Montpellier Parade

Cheltenham

Glos GL50 1UA

UK

Edward Elgar Publishing, Inc.

136 West Street

Suite 202

Northampton

Massachusetts 01060

USA

A catalogue record for this book

is available from the British Library

\section{Library of Congress Cataloguing in Publication Data}

Reforming intergovernmental fiscal relations and the rebuilding of Indonesia : the

"big bang" program and its economic consequences / edited by James Alm, Jorge Martinez-Vazquez, Sri Mulyani Indrawati.

p. cm. -- (Studies in fiscal federalism and state-local finance)

Papers originally presented at a conference entitled "Can Decentralization Help

Rebuild Indonesia?" held in Atlanta, Ga. in May 2002, at the Andrew Young

School of Policy Studies, Georgia State University.

Includes bibliographical references.

1. Intergovernmental fiscal relations--Indonesia. 2. Central-local government relations--Indonesia. 3. Fiscal policy--Indonesia. 4. Decentralization in government--Indonesia. I. Alm, James. II. Martinez-Vazquez, Jorge. III. Indrawati, Sri Mulyani, 1962- IV. Series.

HJ1374.R44 2004

$336.598--\mathrm{dc} 22$

2004048264

ISBN 1843764512

Typeset by Manton Typesetters, Louth, Lincolnshire, UK.

Printed and bound in Great Britain by MPG Books Ltd, Bodmin, Cornwall. 


\section{An analysis of Indonesia's transfer system: recent performance and future prospects}

\section{Bambang Brodjonegoro and Jorge Martinez- Vazquez}

\section{INTRODUCTION}

Since the mid-1970s, fiscal decentralization in Indonesia had been a slowburning affair. However, with the 'Big Bang' of the 1999 reforms, in the space of one year Indonesia changed from one of the most centralized to one of the most decentralized countries in the world. It was with significant trepidation that observers saw the share of sub-national government spending in total government spending almost double from 2000 to 2001 , to over 30 percent, and at the same time over two million civil servants and thousands of facilities were re-assigned to local level. However, the widespread concerns about chaos and disarray did not materialize. The transition to the new decentralized system had some bumps, but overall was fairly smooth.

In hindsight, there are many reasons for this largely successful transition. There is little doubt that, despite some defects, the institutional framework for fiscal decentralization, laid out in Laws No. 22/1999 and No. 25/1999, deserves much credit for the success. The centerpiece for the new fiscal decentralization institutions in Indonesia is the new system of transfers comprising revenue sharing of natural resources, personal income tax, and property taxes, the DAU (Dana Alokasi Umum) a large unconditional grant intended to fund sub-national governments in an equalizing manner, and the DAK (Dana Alokasi Khusus), a set of yet to-be-developed conditional grants.

In this chapter we examine the performance of this transfer system. We first discuss the history of transfers in Indonesia. We next review the structure and performance of the new system of transfers in Indonesia, and then focus on the unfinished agenda for reform. Our main conclusion is that, with the development and initiation of the DAU in 2001, the government of Indonesia (GOI) got the fundamental concepts right but also got many of the particular details wrong. The performance of the DAU was hindered by several choices 
made in the implementation of the new system, the most important being an extremely rigid interpretation of the 'hold harmless' provision. The GOI proceeded to reform the DAU for 2002, and, although real improvements were made, some important issues still remain, including how the new system should move away from the suffocating grip of the hold harmless provision. Also, the GOI faces important challenges but also good opportunities in shaping and increasing the importance of the DAK conditional grant system. With respect to revenue sharing on a derivation basis, we recommend that the GOI should not develop it further, but instead it should focus on developing the revenue autonomy of sub-national governments. ${ }^{1}$

\section{A BRIEF HISTORY OF TRANSFERS IN INDONESIA}

Transfer systems have a long history in Indonesia. From the time of independence in 1945, Indonesia's experience with intergovernmental fiscal finance can be classified into three periods: a pre-SDO period, an SDO period and the current DAU period.

The pre-SDO period extends from 1945 to 1972 . During this time, there were many forms of intergovernmental transfers, often introduced to reduce tensions between central and local governments. Until 1956, the stated goal was to ensure local governments had the ability to finance their planned budget deficits through central government subsidies. Not surprisingly, central government was not able to operate the system and largely had to avoid its original commitment. In 1956, the government issued Law No. 32/1956 with a defined concept of intergovernmental fiscal transfers based on a formula. This proved to be too advanced for the time and never got off the ground, but the Law was not canceled until 1999.

From 1956 to 1964 , the central government introduced a tax revenue sharing scheme in which local governments received some percentage of central government tax revenue. In 1965, the central government replaced the tax sharing system with direct subsidies that were based on the total wage bill of local governments. The scheme was called the 'intergovernmental subsidy system,' and it would become the basic concept later applied in the Subsidi Daerah Otonom (SDO), or Autonomous Region Subsidy. Over approximately the same period (1965-74), central government applied other types of intergovernmental transfers, such as central government contributions to local governments, development assistance funds, natural resources revenue sharing (in terms of royalties for forestry products), and land rent for mining activities. However, these other transfers often lacked an adequate legal basis.

The SDO system was first fully implemented in 1972/73. The core concept behind the SDO was that central government would fully support the costs of 
local government employees. Two-thirds of the SDO was allocated to provincial governments, and the rest was for the district/municipality governments. The SDO is best classified as a specific purpose or conditional grant with no discretion at local government level. Aside from the SDO, local governments also received Instruksi Presiden, or INPRES transfers, which were earmarked for local development activities. An important objective of the INPRES system was to reduce regional disparities, and its allocation was based on several criteria such as population, local own revenue (PAD), a minimum transfer per local government, area, previous transfers, and so on. In reality, there were many types of INPRES grants. Some of them could be classified as specific purpose grants (e.g. INPRES for basic education, health services, reforestation, or small retailers). Others could be classified as general purpose or block grants (e.g. INPRES for provincial development, district/municipality development, or village development). General purpose (or block) INPRES grants generally had larger funding than specific purpose INPRES grants. Both SDO and INPRES were Indonesia's transfer system until the introduction of the DAU in $2001 .^{2}$

\section{THE CURRENT SYSTEM OF TRANSFERS IN INDONESIA}

Law No. 25/1999 introduced three types of intergovernmental transfers: revenue sharing, the DAU, or General Allocation Fund, and the DAK, or Specific Allocation Fund. We will consider each in turn.

\section{Revenue Sharing}

Three types of taxes are currently shared between the central and sub-national governments on a modified derivation basis. These are natural resource taxes, personal income tax, and property taxes (the property tax or PBB, and the land transfer fee or BPHTB). The most significant of the three is natural resources revenue sharing. This is a new type of revenue sharing, introduced by Law No. 25/1999 with the intention of compensating natural resource-rich regions that had felt unfairly exploited during the Soeharto era and that more recently had demonstrated their aspirations to controlling and benefiting from the natural resources in their territories. There are four natural resource commodities whose tax revenues are shared between central and local governments: gas and oil, general mining, forestry and fishery. At the sub-national level of government, there is revenue sharing among the provincial governments, the producing district/municipal governments, and other district/ municipal governments within provinces. The revenue sharing rates for natural resource taxes are shown in Table 8.1. 
Table 8.1 Natural resources revenue sharing scheme (in percent of total revenues collected)

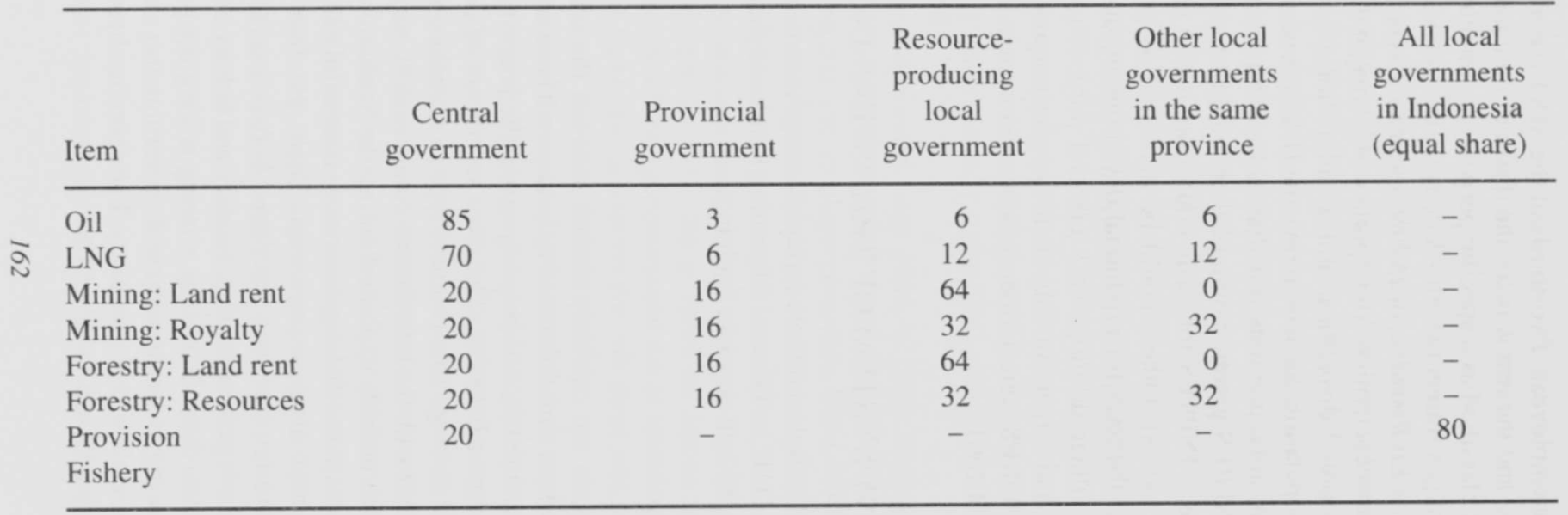

Source: Law No. 25/1999 and Government Regulation No. 104/2000. 
Revenue sharing of natural resources has remained controversial since Law No. 25/1999 because several of the resource-rich regions still seemed to believe that they were not getting a fair share. One part of the problem has been the lack of transparency in the calculations of total revenues from natural resources, and another has been the sharing rates.

In response to the tensions surrounding the sharing of natural resource revenues, central government approved in 2001 special regimes for the most politically assertive provinces, Aceh and Papua. These laws represented the first important instance in which central government legally accepted asymmetric treatment of subnational governments. ${ }^{3}$ Aceh's Special Autonomy Law No. 18/2001 gives this province an additional 55 percent of petroleum taxes and 40 percent of gas taxes, compared to the standard 15 percent and 30 percent, respectively. This means that the special autonomy scheme gives Aceh 70 percent of oil and gas revenue sharing. Papua's Special Autonomy Law No. 21/2001 applies a similar proportion. ${ }^{4}$ In both special autonomy laws, the whole additional revenue from petroleum and gas taxes will be received directly by their respective provincial governments and the provincial governments will be responsible for allocating the fund to all of their kabupaten and municipalities using their own formula.

Revenue sharing for personal income tax was first introduced with the 1999 reforms. Property tax and land transfer fee revenues were already shared between central and local governments prior to the 1999 reform. Through the revision of income tax law (Law No. 17/2000), central government added personal income tax (including payroll tax) to the tax sharing scheme, where 80 percent of personal income tax revenues are still retained by central government and the rest goes to provincial ( 8 percent) and district/ municipal governments (12 percent). ${ }^{5}$ Table 8.2 gives the sharing rates for other taxes.

Revenue sharing on a derivation basis is helping with general funding of sub-national governments, and thus is being used as a way to address vertical imbalances in Indonesia. Revenue sharing is also being used to address the important political issue of redressing perceived past injustices toward natural resource-endowed regions. But revenue sharing can also be a source of problems, the most serious of which is increasing fiscal disparities; however, this is a problem that can be addressed through equalization transfers. It is notable that Indonesia has avoided so far the problems associated with revenue sharing arising from the difficulty encountered with the fair apportionment of taxes such as VAT or corporate income tax. It was a wise decision not to share those taxes with sub-national governments, and it should be kept that way. 
Table 8.2 Other taxes revenue sharing scheme (in percent of total revenues collected)

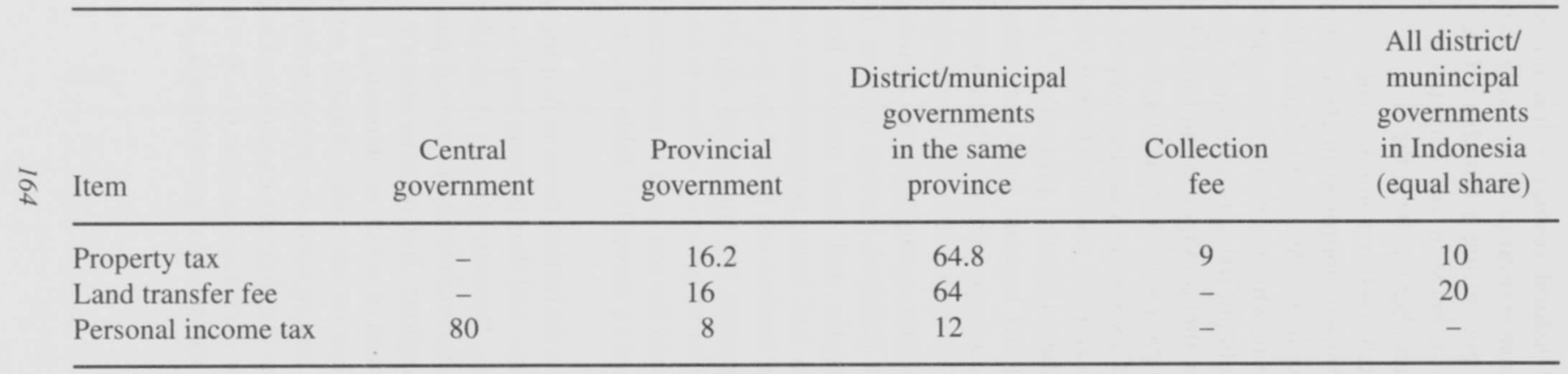

Source: Government Regulation No. 104/2000 and Law No. 17/2000. 


\section{Dana Alokasi Umum (DAU), or the General Allocation Fund}

The DAU is by far the most important type of transfer in Indonesia, and finances approximately three-fourths of sub-national government expenditures. The DAU can be classified as a general purpose grant that gives full discretion to local governments to spend the funds according to their priorities. The DAU is a well-developed equalization grant system with explicit funding rules and formulas for the distribution of the funds. The overall pool of funds comes from 25 percent of net domestic revenues (or total domestic revenue minus revenue sharing) in the central government budget. From that amount, provinces receive 10 percent and district/municipal governments 90 percent. Details of the formula used for the allocation of DAU in 2001 and 2002 are shown in Appendix 8.1. The formula is practically identical for provinces and district/municipal governments.

The basic concept behind the DAU formula is the fiscal gap, or the difference between measures of expenditure needs and fiscal capacity for each local government. The expenditure needs for each jurisdiction are approximated by applying a weighted index of four variables (population, area, cost differences, and poverty) to the average expenditure for all jurisdictions. The fiscal capacity of each jurisdiction is approximated by adding an estimate of its own revenues to the actual revenues from shared taxes.

In fact, however, only 20 percent of the DAU overall funds were allocated through the formula in 2001; in 2002 this figure increased, but only to 40 percent. The rest of the DAU funds were allocated to the provinces and districts/municipalities on the basis of two additional sets of factors. The first factor was a lump sum or equal amount that each jurisdiction (province and district/municipality) received during the fiscal year. The lump-sum factor represented 10 percent of the total DAU funds in 2002, as specified by Parliament. ${ }^{6}$ The lump-sum factor has been justified as covering fixed or overhead costs of the jurisdictions. However, it is feared that this has given an incentive for the further fragmentation of local governments.

The second additional factor governing the final allocation of the DAU is the so-called 'balancing factor,' predicated on the basis of a 'hold harmless' condition. The balancing factor for 2001 was proposed by the Ministry of Finance and applied only to the districts and municipalities, and assured that every district/municipality received a minimum transfer equal to 130 percent of the SDO funds and 110 percent of the INPRES funds it got in 2000. This second factor took the bulk of the DAU funds in 2001. The interpretation of the hold harmless provision in 2002 was demanded by Parliament as meaning that no jurisdiction would get less than the funds it got in 2001. This meant that in addition to the 10 percent of the DAU going to the lump sum factor, an additional 50 percent of the DAU went to the balancing factor in 2002. The 
funds of the balancing factor in 2002 were distributed among local governments in proportion to their relative wage bill for public employees. ${ }^{7}$ As will be discussed further, the balancing factor could have worked against the objective of equalization in the DAU, ${ }^{8}$ but also introduced in 2002 an incentive for local governments to hire more employees and to spend more on salaries.

Law No. 25/1999 emphasized the equalization role of the DAU, but in reality the DAU has served several objectives other than equalization. By virtue of the 'balancing factor,' all jurisdictions receive a DAU amount no matter how well off they are. This means that the DAU functions as a general funding mechanism to address vertical imbalances. The DAU is also being used as a way to redress historical injustices. ${ }^{9}$

A recent government regulation requires that local governments report on the uses of the DAU on a quarterly basis. This regulation raises the question of whether the DAU will remain an unconditional grant in the future. We will discuss the possibility of transforming some of the funds now used for the balancing factor into conditional grants. However, the question with reporting requirements and even more so with any conditionality is whether the central authorities have the means to monitor and enforce them.

\section{Dana Alokasi Khusus (DAK), or the Specific Allocation Fund}

Law No. 25/1999 introduces specific purpose, or conditional, grants for two types of objectives: to help fund important needs which cannot be incorporated in the DAU formula ${ }^{10}$ and to provide funding for activities which relate to national priorities or commitments. " A third category contemplated as part of the DAK is a mechanism for intergovernmental sharing of forest exploitation fees.

The DAK is still a minor part of Indonesia's system of intergovernmental transfers. The DAK is seen in law as a conditional matching grant, and local governments receiving DAK funds are supposed to provide at least 10 percent of the total amount of the project on their own. ${ }^{12}$ The source of funding for the DAK is the central government budget, except for reforestation activities, which are covered directly by fees from the reforestation fund. ${ }^{13}$

Except for reforestation funds, the DAK system was not used in either 2001 or 2002. Two questions arise. First, from where is the funding for the DAK to come? One answer commonly offered is that some of the development expenditures now going through central government agencies could be transformed into conditional grants as part of the DAK (Hofman et al., 2002). Another possibility is to use some of the funds now used as the balancing factor in the DAU as funding for conditional grants in the DAK. This issue is not yet resolved. Second, on what basis should the DAK be allocated? The 
approach for DAK allocation is vague in the Law, and this lack of transparency may eventually raise questions of arbitrariness. Several approaches are possible to bring transparency in the DAK. The funds may be distributed as part of national sectoral programs, which may include investments in capital infrastructure and could be distributed according to clear and objective criteria summarized in explicit formulas. DAK funds may also be used as contingency funds for natural disasters. Regardless, rules should be established for the annual allocation, the authority to disburse, and the final disposition. In general, DAK funds should be distributed to achieve central government goals such as stimulating regional spending on activities of national interest or addressing externalities across regional governments; redistribution need not be emphasized if the DAU does a sufficient job in equalizing fiscal disparities. In this regard, remember that during 2001 and 2002 the DAU was severely constrained in its equalization role. If these constraints continue in the future, then it may be necessary to consider an equalization role for the DAK.

\section{Recent Changes in the DAU}

A remarkable feature of the new system of transfers in Indonesia has been an officially guided process of rigorous examination and improvement. This is good because the short time available to put together the DAU in 2000, from principles to the most concrete details of implementation, inevitably meant that the new transfer system would have problems. These problems were indeed numerous. However, the DAU also got may things right, and these were in general the very fundamental aspects of the transfer system (MartinezVazquez, 2001).

The accomplishments of the DAU in 2001 were in three areas. First, the government used a transparent rule for how to fund the DAU, and also clearly established the division of the overall pool of funds between the two tiers of regional governments, the districts/municipalities and the provinces; this funding rule was kept for the second year. Second, the formula used for the DAU looked at the difference between estimated expenditure needs and revenue capacity as opposed to actual expenditures and actual revenues of regional governments. This avoided moral hazard problems of providing incentives to regional governments to spend more and collect too little in an attempt to increase their DAU allocations. Third, the DAU used a phased-in approach, although the 'hold harmless' provision was carried too far.

There were also in 2001 several questions and several problems with the DAU. There were questions about the adequacy of the DAU overall funding at 25 percent of central government domestic revenues, as well as questions about ways to improve on the variables used in the estimation of fiscal or 
expenditure needs and the weights attached to them. ${ }^{14}$ Among other problems, the DAU formula lacked aggregate consistency because some of the variables in the definition of fiscal capacity and expenditure needs were not properly scaled. Another problem was that the computation of fiscal capacity applied an index of industry, natural resources, and human resources, equally weighted, both to 'local own revenues' and to 'shared revenues.' Instead, the index should have been applied only to 'local own revenues'; the other component, 'shared revenues', should have been entered in the formula directly as forecast by the government authorities. The reason for using an estimate for fiscal capacity is that there exists a moral hazard problem with using direct estimates of revenues. When direct estimates of revenues are used in the formula, local governments are given an incentive to collect less revenue by lowering tax enforcement and administration efforts, by lowering tax rates, or modifying the tax base (assuming they have discretion over any of those dimensions of actual revenue effort). In the case of Indonesia, local governments have some discretion over the level of tax effort they can exercise for local own revenues. However, they have no discretion at all over shared revenues. This of course raises the question of whether local governments with a negative fiscal gap would receive zero funds from the DAU. ${ }^{15}$

During the first few months of the implementation of the DAU in 2001, it became clear that the government would have to review an important issue related not to the structure of the DAU but rather to its implementation process. This was the 'hold harmless' provision. The analysis used to back up the quantification of the 'balancing factor' had been incomplete, and ultimately led to erroneous policy because the budgetary position of local governments in 2001 was very different from their respective position in 2000. There were big differences arising from major changes in expenditure assignments, as specified in Law No. 22/1999, and from changes in revenue assignments, including revenue sharing in natural resources. Therefore, providing regional governments with transfers at least equal to the SDO and INPRES funds they got in 2000 did not guarantee they were held harmless in the new fiscal environment of 2000. The 'hold harmless' provision should have been framed better by comparing the old plus new expenditure assignments (where the latter should have been costed at the level of funding required in the last year before those responsibilities had been decentralized) against own regional government revenues plus new resources from revenue sharing plus new transfers from DAU and special allocation grants; the DAU and special allocation grants should have been at least as large as the SDO and INPRES transfers in 2000. However, it must be noted that even this would not have been sufficient to hold harmless local governments; that is, the DAU transfers in 2001 may have exceeded the SDO and INPRES transfers in 2000 , but the remainder may have been less than the funding required 
for the new expenditure assignments net of revenue sharing. On the other hand, some regional governments may have received so much more funding through revenue sharing in 2001 that they would have been held harmless even without DAU transfers. In such cases, holding harmless would not have required the transfer of funds equivalent to SDO and INPRES received in 2000 , when there was no revenue sharing.

Even though it was not possible to phase out the hold harmless provision in the 2002 DAU, the reformed DAU represents a marked improvement over the 2001 DAU. The major improvement occurred on the revenue side. In 2002, all revenue components reflected capacity coming either from actual revenue sharing or from estimated local capacity. On the expenditure side, progress has been slower due to limited data availability.

\section{THE RATIONALES FOR TRANSFERS IN INDONESIA}

There are several reasons for intergovernmental transfers, both in general and in the specific case of Indonesia. This section considers these justifications.

\section{To Correct Vertical Imbalances}

One of the most important objectives of the intergovernmental transfer system in Indonesia is to reduce vertical imbalances. The decentralization process has transferred significant expenditure responsibilities to sub-national governments, which now require more reliable sources of financing. The questions, of course, are whether there is a vertical imbalance now in Indonesia, and, if so, how significant this imbalance is.

There is no unique definition of vertical imbalances. Broadly speaking, a vertical imbalance arises when there is no correspondence between the expenditure responsibilities and the revenue sources assigned to each level of government. Several approaches are used to measure the presence and importance of vertical imbalances.

One approach is to identify the existence of persistent budget deficits at a particular level of government. Here, the size and persistence of the deficits is taken as prima facie evidence of such an imbalance. Independently of its accuracy, this diagnostic tool cannot be used for Indonesia because there is no information available on sub-national government deficits for recent years. ${ }^{16}$

Another approach is to quantify expenditure needs or requirements at different levels of government and then to compare them to available resources. One possible outcome here is that both central government and sub-national governments are short of funds, since there is inherent ambiguity associated with the expenditure levels (quantity and quality of services) that can be associated with 
the assignment of expenditure responsibilities at each level of government. One way currently being debated in Indonesia of dealing with this ambiguity is to do an exhaustive listing of standards or norms for provision and to conduct an accounting of the expenditures required for explicitly stated and agreed upon levels and quality of public services. This approach is very costly and time consuming, and also requires a significant degree of intergovernmental consensus and communication. Without these, the listing and costing of expenditure norms can lead to intergovernmental friction and poor budgeting practice. ${ }^{17}$

A third approach to identifying vertical imbalances is to examine to what extent different levels of government are able to finance expenditures from their own sources of revenues. The attraction of this approach is that it bypasses the uncertainty surrounding any measurement of government needs. A simple and effective guarantee against vertical imbalance is to provide each level of government with enough revenue autonomy so that they can make their own decisions regarding what services to cover and at what level. By this measure, there is considerable vertical imbalance against sub-national governments in Indonesia.

Current local tax power only contributes a small proportion of the total tax revenue in Indonesia, and it is far from enough to finance most of the new expenditure responsibilities transferred to local governments. Table 8.3 shows that local own revenue (local taxes and charges) only contributed between 3 4 percent during the two fiscal years, 2000 and 2001. Clearly, it will be impossible for local governments in Indonesia to finance their basic needs or basic expenditures if their sources are only local own revenues.

Table 8.3 Central and local fiscal indicators, 1998-2001 (in percent)

\begin{tabular}{lccc}
\hline Fiscal year & $\begin{array}{c}\text { Local/total } \\
\text { expenditure }\end{array}$ & $\begin{array}{c}\text { Local own/ } \\
\text { total revenue }\end{array}$ & $\begin{array}{c}\text { Intergovernmental transfer/ } \\
\text { total local expenditure }\end{array}$ \\
\hline $1998 / 00$ & 15.81 & 3.31 & 97.19 \\
$1999 / 00$ & 16.61 & 3.63 & 79.23 \\
2000 & 17.88 & 3.10 & 85.87 \\
$2001^{*}$ & 24.82 & 3.80 & 103.04 \\
\hline
\end{tabular}

Notes:

Total expenditure $=$ National expenditures - Intergovernmental transfer + Total local expenditure

Total revenue $=$ National revenue + Local own revenue

Local revenue $=$ Local own revenue + Intergovernmental transfer

* Estimated data for 2001 using proposed budget.

Source: Authors' calculations. 
The current practice in Indonesia of measuring vertical imbalances has been to examine whether the 25 percent funding for the DAU, together with own revenues (PAD) and shared revenues, has been enough to finance old and new expenditure responsibilities. Often, even this practice reduces to examining whether the cost of personnel attached to a level of government can be covered by the overall funds made available to that level of government. The most authoritative study of this question is by Lewis (2001), who concludes that, while provincial government may have been a bit short in 2001 , the districts/municipalities were amply funded. Clearly, the transfer system, especially the DAU, plays a key role in reducing the possible vertical fiscal imbalances between central and local governments.

\section{To Reduce Horizontal Imbalances}

Horizontal imbalances arise from existing fiscal disparities across sub-national jurisdictions. Sub-national governments generally have different tax capacities because they differ in their economic bases. In Indonesia there are significant disparities in gross regional product per capita (GDRP 1999 per capita). At district/municipality level (Table 8.4), the coefficient of variation in 1999 was 2.12 , and the maximum value was 172 times higher than the minimum value. At provincial level, the corresponding values are lower, with a coefficient of variation of 0.93 and a gap between maximum and minimum of 16 times (Table 8.5).

There are also significant disparities for actual revenues collected. For example, the coefficient of variation for districts/municipalities for own revenues per capita in 1999 (Total collection per capita in Table 8.4) is 2.24 and for shared revenues in 2001 (Revenue share per capita in Table 8.4) is 2.91. The coefficients of variation for these two variables for the provinces are a bit lower but still quite high.

Horizontal fiscal imbalances also may exist because of disparities across sub-national jurisdictions in expenditure needs. The differences in needs may arise from either different prices or costs of service provision or from different shares of the population with special needs. Tables 8.6 and 8.7 show that there is little variation in price levels as measured by the construction price index (Const index). However, there are significant disparities in the incidence of population living under the poverty level (Pct poor) and other expenditure need-generating features, such as the percent of the population of school age, the percent of the population that is elderly, and population density. Disparities in both fiscal capacity and expenditure needs highlight the important role equalization transfers need to play in Indonesia. 
Table 8.4 District/municipality disparities in revenues and fiscal capacity (in thousands of rupiahs)

\begin{tabular}{|c|c|c|c|c|c|}
\hline Variable & Mean & $\begin{array}{l}\text { Standard } \\
\text { deviation }\end{array}$ & $\begin{array}{l}\text { Coefficient } \\
\text { of variation }\end{array}$ & Maximum & Minimum \\
\hline GRDP 1999 per capita & 4901.20 & 10372.08 & 2.12 & 147676.76 & 856.50 \\
\hline Total collection 1999 per capita & 22.42 & 50.31 & 2.24 & 855.25 & 0.30 \\
\hline Revenue share 2001 per capita & 157.12 & 457.23 & 2.91 & 4853.57 & 6.41 \\
\hline DAU 2001 per capita & 445.19 & 365.02 & 0.82 & 3376.53 & 89.68 \\
\hline After DAU 2001 per capita & 467.61 & 369.80 & 0.79 & 3395.64 & 105.33 \\
\hline After all transfer 2001 per capita & 624.73 & 721.56 & 1.15 & 6984.57 & 137.76 \\
\hline Regional revenue 2001 per capita & 637.39 & 719.41 & 1.13 & 6984.57 & 142.46 \\
\hline DAU 2001 (\% of expenditure) & 96.95 & 23.97 & 0.25 & 203.67 & 42.74 \\
\hline DAU 2002 per capita & 522.55 & 393.35 & 0.75 & 3376.53 & 110.76 \\
\hline After DAU 2002 per capita & 544.96 & 398.66 & 0.73 & 3395.64 & 128.81 \\
\hline After all transfer 2002 per capita & 702.08 & 727.77 & 1.04 & 7041.28 & 160.19 \\
\hline Regional revenue 2002 per capita & 710.83 & 729.76 & 1.03 & 7048.95 & 162.53 \\
\hline Expenditures 2001 per capita & 453.97 & 309.72 & 0.68 & 2934.81 & 100.70 \\
\hline
\end{tabular}

Source: Authors' computations. See Appendix 8.2 for a full definition of all variables. 
Table 8.5 Province disparities in revenues and fiscal capacity (in thousands of rupiahs)

\begin{tabular}{|c|c|c|c|c|c|}
\hline Variable & Mean & $\begin{array}{l}\text { Standard } \\
\text { deviation }\end{array}$ & $\begin{array}{l}\text { Coefficient } \\
\text { of variation }\end{array}$ & Maximum & Minimum \\
\hline GRDP 1999 per capita & 4977.53 & 4614.32 & 0.93 & 23465.08 & 1429.58 \\
\hline Total collection 1999 per capita & 23.73 & 38.56 & 1.62 & 201.90 & 5.22 \\
\hline Revenue share 2001 per capita & 42.14 & 93.79 & 2.23 & 412.51 & 3.14 \\
\hline DAU 2001 per capita & 50.03 & 30.80 & 0.62 & 151.47 & 13.02 \\
\hline After DAU 2001 per capita & 70.60 & 50.32 & 0.71 & 271.93 & 17.65 \\
\hline After all transfer 2001 per capita & 112.74 & 132.72 & 1.18 & 572.30 & 25.88 \\
\hline Regional revenue 2001 per capita & 125.96 & 132.75 & 1.05 & 594.46 & 26.08 \\
\hline DAU 2001 ( $\%$ of expenditure) & 62.66 & 87.43 & 1.40 & 414.19 & 18.26 \\
\hline DAU 2002 per capita & 72.31 & 50.88 & 0.70 & 185.21 & 11.10 \\
\hline After DAU 2002 per capita & 92.88 & 59.10 & 0.64 & 265.83 & 19.37 \\
\hline After all transfer 2002 per capita & 135.02 & 121.40 & 0.90 & 566.20 & 27.60 \\
\hline Regional revenue 2002 per capita & 140.46 & 131.80 & 0.94 & 594.50 & 27.60 \\
\hline Expenditures 2001 per capita & 130.50 & 84.11 & 0.64 & 301.87 & 4.26 \\
\hline
\end{tabular}

Source: See Appendix 8.2 for a full definition of all variables. 
Table 8.6 District/municipality disparities in expenditure needs

\begin{tabular}{lrrrrr}
\hline Variable & Mean & $\begin{array}{r}\text { Standard } \\
\text { deviation }\end{array}$ & $\begin{array}{l}\text { Coefficient } \\
\text { of variation }\end{array}$ & Maximum & Minimum \\
\hline Pct poor (\%) & 24.53 & 15.25 & 0.62 & 91.12 & 0.99 \\
Pct labour (\%) & 39.85 & 7.37 & 0.18 & 77.05 & 13.25 \\
Pct school age (\%) & 15.80 & 4.81 & 0.30 & 41.31 & 4.18 \\
Pct old (\%) & 3.45 & 1.98 & 0.58 & 10.14 & 0.05 \\
Pct young (\%) & 28.55 & 6.64 & 0.23 & 44.46 & 12.10 \\
& & & & & \\
Area (km) & 5763.13 & 10712.69 & 1.86 & 119749.00 & 16.46 \\
Density (per km) & 976.75 & 1894.20 & 1.94 & 12744.48 & 0.86 \\
Const index & 135.27 & 18.51 & 0.14 & 258.90 & 113.20 \\
\hline
\end{tabular}

Source: Authors' computations. See Appendix 8.2 for a full definition of all variables.

Table 8.7 Province disparities in expenditure needs

\begin{tabular}{lrrrrr}
\hline Variable & Mean & $\begin{array}{r}\text { Standard } \\
\text { deviation }\end{array}$ & $\begin{array}{c}\text { Coefficient } \\
\text { of variation }\end{array}$ & Maximum & Minimum \\
\hline Pct poor (\%) & 24.58 & 12.64 & 0.51 & 55.81 & 4.53 \\
Pct labour (\%) & 41.58 & 12.12 & 0.29 & 88.11 & 23.35 \\
Pct school age (\%) & 17.58 & 6.51 & 0.37 & 44.71 & 9.12 \\
Pct old (\%) & 3.18 & 1.54 & 0.49 & 7.96 & 0.88 \\
Pct young (\%) & 30.68 & 10.59 & 0.35 & 73.14 & 16.34 \\
& & & & & \\
Area (km) & 6469.1 & 81718.08 & 1.27 & 414039.95 & 661.62 \\
Density (per km) & 648.71 & 2294.68 & 3.54 & 12673.22 & 5.28 \\
Const index & 134.82 & 14.77 & 0.11 & 203.44 & 116.34 \\
\hline
\end{tabular}

Source: Authors' computations. See Appendix 8.2 for a full definition of all variables.

\section{To Address Externalities and Interjurisdictional Spillovers, Central Government Policy Objectives, and the Implementation of National Programs at Local Level}

Indonesia currently has no conditional transfers. Most countries use some form of conditional transfers in support of sub-national governments for expenditure areas such as roads, water and sewerage treatment plants, transportation, housing, education, health, and so on. However, there is considerable variety across countries in the objectives pursued and the actual structural design of capital transfers. An important sub-category of conditional grants is that of capital transfers. The typical country has a variety of capital transfers that are closed-funded in the national budget, provide earmarked funds within 
specific capital expenditures and, as is the case for the DAK in Indonesia, require some level of matching funds from sub-national governments. ${ }^{18}$ The funds are commonly allocated either by an objective formula or on a specific project basis.

Conditional transfers and capital transfers may be used for many different objectives. Common objectives for conditional transfers include:

- addressing externalities at sub-national level because of spillover effects of some services or infrastructure across sub-national jurisdictions;

- addressing vertical imbalances in the assignment of revenues in favor of central authorities;

- addressing limitations with borrowing at sub-national level either because of borrowing limits and other restrictions or because of lack of credit availability;

- rewarding sub-national expenditure in areas of particular national importance or in support of national programs actually implemented at regional and local levels.

In the case of Indonesia, expenditure responsibilities for health and education for example are at sub-national level as mandated in Law No. 22/1999. If these services produce positive externalities, it is likely that local governments may currently be under-spending on them. Since the DAU is not intended to accommodate specific central government objectives, the government will have to rely on the DAK. However, some parts of central government still feel strongly that it is not appropriate to promote the DAK mechanism in pursuing national objectives. Instead, they favor a deconcentration mechanism in the form of Daftar Isian Proyek (DIP), or Development Project List. The total deconcentrated fund is not very far behind the total funds allocated to intergovernmental transfers. The persistence of the DIP is seen by many observers as an indication that central agencies still want to show their power in the regions.

Note that the use of central government funds earmarked exclusively for capital investment at sub-national level means that central authorities have identified a need to enhance capital expenditures at sub-national level, as opposed to recurrent or ordinary expenditures. This need may arise from the existence of externalities across sub-national jurisdictions or from financing constraints sub-national governments face vis-à-vis lumpy capital expenditures. ${ }^{19}$ Often, central authorities have a bias toward earmarking a large share of central government transfers for capital expenditures at sub-national level. This reflects an ingrained belief that capital expenditures are always more efficient than recurrent expenditures. Of course, there are no sound bases for this extreme position. The production of public services requires different 
recurrent and capital input mixes, and the optimal mix should basically reflect the prices of different inputs and the physical requirements of available technologies ${ }^{20}$ From an equity viewpoint, capital transfers may be used to redress inequities in the distribution of capital infrastructure that arose in the past. ${ }^{21}$

\section{HOW HAS INDONESIA'S NEW TRANSFER SYSTEM PERFORMED TO DATE?}

\section{Has Budget Autonomy Been Preserved?}

One of the basic principles in the Indonesian decentralization process has been to give greater autonomy to local governments in managing their own budgets. Although it is true that the vast majority of revenue sources for subnational governments are under the control of central authorities, local governments seem to have a significant degree of discretion to spend the funds according to their budget priorities, once the money is in their hands. ${ }^{22}$ Ironically, local governments have been slow in moving away from past practices. Many local governments during 2001 appeared to have thought that the DAU was intended to pay all local civil servant salaries as the SDO did in the past. This misconception of course has been reinforced in 2002 by the computation of the 'balancing factor' on the basis of the past wage bill.

\section{Has Revenue Adequacy for Provinces and Districts/Municipalities Been Maintained?}

The new system of transfers has gone a long way toward ensuring 'revenue adequacy' during the past two years. As we have seen, the most significant component of the DAU allocations in 2001 and 2002 was the 'hold harmless' provision. These funds were supposed to allow local governments to pay all of their local civil servants, including the ones transferred from the central government offices in 2001. In addition, central government budgeted for a 'contingency fund' in 2001 and again in 2002 to allow for additional finance needed by local governments with a mismatch between transferred personnel and available fiscal resources. ${ }^{23}$

The claims for additional resources by local governments during 2001 had several sources. First, the transfer of central government employees was not entirely smooth, and many provincial governments ended up with more transferred employees than expected. Second, there was a (convenient) misconception among local governments that only DAU funds could be used to pay local civil servants. Even though some local governments had additional sources of 
revenues such as from revenue sharing, they refused to use those additional funds to pay their employees' salaries. Third, in the middle of 2001, central government suddenly mandated an increase in civil servant salaries, retroactive to January 1 . This policy affected all civil servant salaries without any exception, and imposed an additional obligation on local governments. Because the DAU 2001 had been formulated using pre-2001 salary data, it was not surprising that some local governments had to ask for additional funds.

It has been argued there is still another reason why local revenues might not be adequate. This is related to how the DAU itself is formulated, especially on the expenditure need side. Due to the unavailability of minimum standards of public service, expenditure needs are approximated, not calculated. This means that the estimation of expenditure needs might not reflect the real needs of local governments. However, this argument again assumes that it is politically feasible and fiscally affordable to develop an exhaustive list of budgetary standards at local level. International experience shows that these are difficult tasks to perform.

\section{Have Transfers Been Stable?}

Stability of transfers is a desirable characteristic because it facilitates local government budgeting and planning. While flows from the DAU have been remarkably stable, the story is very different for revenue sharing transfers. The stability of the DAU has been based on the permanency of the funding rule (at least 25 percent of net domestic revenue), and also on the fact that central government allocated the funds anticipated in the budget as opposed to the funds actually collected by the tax authorities. This arrangement has allowed central government to transfer the DAU funds on time every month.

In contrast, for revenue sharing the transfer of funds has not been stable and has not been on time either. Central government originally promised to implement the actual transfer quarterly; instead, the first transfer received by local governments occurred after six months in 2001. A similar pattern was repeated in 2002, both for natural resources revenue sharing and for other tax revenue sharing, due in part to the difficulty of gathering full information on actual revenue collections in the regions. With these revenues there can be no guarantee that the amount of sharing will be stable or similar from year to year, but the central authorities need to make an effort to improve the frequency of the payments.

\section{Is the Current System of Transfers Transparent and Simple?}

The current intergovernmental system still cannot be considered reasonably transparent and simple. For the DAU as the major part of the transfer, 
transparency has increased through different efforts such as book publication, dissemination ('socialization'), and, most importantly, the use of a standard formula to allocate the funds. However, the 2002 DAU was still not 'simple' enough because of the pressure exercised by natural resourcerich regions and the 'hold harmless' provision insisted upon by Parliament. The original formula might have been simple but the final formula became quite complicated and relatively difficult to be described even by specialists. The issue of transparency in revenue sharing is complicated by the fact that the supporting data needed to calculate the allocations are not the type of data that are widely available; in fact, some government agencies and ministries still keep the data secret. Local governments naturally have had some difficulties whenever they have tried to reconfirm the calculations. The calculation method itself is far from simple and relatively difficult to understand, especially for natural resource revenue sharing. As a result, except for personal income tax revenue sharing, it is difficult for local governments to predict their possible revenue from the revenue sharing scheme.

\section{Have Transfers Distorted Expenditure Decisions and Discouraged Sub- national Tax Efforts?}

The structure of the DAU formula takes special care not to introduce any distortion in the expenditure decisions of local governments. All the variables used in the estimation of expenditure needs are objectively defined and beyond manipulation by changes in local government behavior. The big exception, however, is the definition and computation of the 'hold harmless' provision for 2002, which, as we have seen, is defined in terms of the local government's wage bill for the previous year. This, of course, gives a significant incentive to local governments to increase their personnel expenditures at the cost of other expenditure priorities.

Law No. 25/1999 implicitly introduces a hard-budget constraint for local governments by designing DAU as a formula-based transfer and revenue sharing as an actual revenue-based transfer. In the new set up, there should be no room for local governments to be 'subsidized' by central government if they have problems with their budgets. The Law clearly states that, if a local government needs additional revenue, then it can borrow directly from financial institutions or by issuing municipal bonds. However, in 2001, the hard budget constraint was partially violated by the introduction of the contingency fund. As mentioned earlier, there were some good reasons why the contingency fund had to be used. A related fact was that because of macroeconomic concerns central government, through presidential decree, prohibited all types of local borrowing. 
What has been the effect of the new transfers on local tax efforts? Because the DAU formula uses estimates of fiscal capacity rather than actual revenues collected, the introduction of the new transfers should not have affected local government 'tax efforts,' defined as the ratio of own tax and fees revenues divided by regional gross domestic product. However, there was the possibility of an 'income effect' whereby the new transfers may have affected tax efforts. To test for the neutrality of the new transfer system on tax efforts, we ran a number of regressions of tax efforts at the provincial and district/municipality levels for 2001 and 2002 on the level of DAU transfers (as a percent of total expenditures), and several other control variables including gross regional product per capita. The results are shown in Tables 8.8 and 8.9 , where we report only the results for 2002; the results for 2001 were very similar.

For provinces (Table 8.8), we find that the higher the DAU contribution in provincial government expenditures, the lower local tax effort. This is a surprising result because provincial governments were a bit shortchanged by the DAU system in 2001, and therefore they should have made an extra effort to collect more of their own revenues. Perhaps provincial governments were attempting to signal to central government there was a need for contingency funds. Also of note are the positive and significant relationships of population density and income tax revenue sharing to tax effort. Higher population density could indicate active economic activities that lead to higher potential tax revenue, while higher income tax sharing indicates higher economic capacity that should generate higher local tax revenue. For the case of districts/municipalities (Table 8.9), we find that the DAU is, as expected, an insignificant factor in local tax effort. Among the other control variables, income tax revenue sharing and population density contribute positively to tax effort.

\section{Have Transfers Been Equalizing?}

It appears that DAU transfers have in general been equalizing (e.g. they have helped dampen fiscal disparities), but not by very much, since fiscal disparities (measured in local revenues per capita) after the DAU remain high. The sharing of natural resource revenues, on the other hand, has been highly unequalizing, which was as expected given the uneven distribution of natural resource endowments across local governments. Other tax sharing has also contributed to fiscal disparities.

The desired extent of equalization is still an open policy question in Indonesia since there has never been a 'white paper' or master plan of decentralization reform with explicitly stated objectives. The DAU itself has lacked formalized performance criteria. This no doubt has complicated the evaluation of the system and its reform in 2002 and later years. 
Table 8.8 Explaining provincial tax efforts in 2002

\begin{tabular}{|c|c|c|c|c|c|c|c|c|}
\hline Independent variable & (1) & (2) & (3) & (4) & (5) & (6) & (7) & (8) \\
\hline Intercept & $0.35635 * *$ & $0.8565^{*}$ & $0.39940^{* * *}$ & 0.7072 & $0.34046 * *$ & $0.7258 *$ & $0.341139 * *$ & $0.7131^{*}$ \\
\hline GRDP 1999 per capita & 0.00000566 & 0.00000916 & -0.00001280 & -0.00000994 & -0.0000092 & -0.00000591 & -0.00001236 & -0.00000959 \\
\hline $\begin{array}{l}\text { DAU } 2002 \text { (pct of } \\
\text { expenditure) }\end{array}$ & - & - & $-0.0006429 * *$ & -0.0006456 & $-0.0007340^{* *}$ & $-0.0007335^{* *}$ & $-0.0006215^{* *}$ & $-0.0006262 * *$ \\
\hline Const index & $0.0006708^{*}$ & $\begin{array}{l}0.0006735^{*} \\
-0.003837\end{array}$ & & -0.002374 & & -0.002951 & & 0.00566 \\
\hline $\begin{array}{l}\text { Density } \\
\text { Income tax (pct of }\end{array}$ & & -0.003837 & $0.00007117 * *$ & 0.00006851 & $0.024280^{* *}$ & $0.023259 * *$ & $\begin{array}{l}0.00008423^{*} \\
0.00624\end{array}$ & $\begin{array}{l}-0.002335 \\
0.00008039 *\end{array}$ \\
\hline $\mathrm{R}^{{ }^{\text {total revenue) }}}$ & & & 0.532 & 0.551 & 0.425 & 0.454 & & 0.0000000 \\
\hline 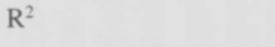 & 0.205 & 0.255 & & & 0.425 & 0.454 & 0.536 & \\
\hline
\end{tabular}

Notes:

The dependent variable in all regressions is provincial tax effort.

* Indicates statistical significance at the 10 percent level; ${ }^{* *}$ Indicates statistical significance at the 1 percent level. 
Table 8.9 Explaining local tax efforts in 2002

\begin{tabular}{|c|c|c|c|c|c|c|c|c|}
\hline Independent variable & (1) & (2) & (3) & (4) & (5) & (6) & (7) & (8) \\
\hline Intercept & $0.5882^{* *}$ & 0.1720 & $0.5310^{*}$ & 0.0008 & $0.4517^{*}$ & 0.0579 & $0.4469 *$ & -0.0147 \\
\hline GRDP 1999 per capita & - & - & -0.00000615 & $-0.00000811^{*}$ & $-0.00000693^{*}$ & $-0.00000838^{*}$ & -0.00000688 & $-0.00000853 *$ \\
\hline $\begin{array}{l}\text { DAU } 2002 \text { (pct of } \\
\text { expenditure) }\end{array}$ & 0.00000593 & $0.0000074 *$ & 0.000211 & -0.000723 & 0.000640 & -0.000122 & 0.000631 & -0.000261 \\
\hline \multirow{4}{*}{$\begin{array}{l}\text { Const index } \\
\text { Density } \\
\text { Income tax (pct of } \\
\text { total revenue) } \\
\mathrm{R}^{2}\end{array}$} & 0.000017 & -0.000768 & & 0.004715 & & 0.003614 & 00001607 & 0.05757 \\
\hline & & 0.003792 & 0.00003718 & $0.00004532 *$ & & & 0.00001687 & $0.004209^{*}$ \\
\hline & & & & & $0.07912 *$ & $0.07743^{*}$ & $0.06686^{*}$ & 0.00002696 \\
\hline & 0.060 & 0.130 & 0.140 & 0.240 & 0.210 & 0.270 & 0.220 & 0.300 \\
\hline
\end{tabular}

Notes:

The dependent variable in all regressions is district/municipality tax effort.

* Indicates statistical significance at the 10 percent level; ** Indicates statistical significance at the 1 percent level. 
Another important complicating factor in the equalization performance of the DAU has been the introduction of the balancing factor or 'hold harmless' provision in the DAU. For example, using a public wage bill criterion to distribute the balancing factor funds in 2001 and 2002 contributed to fiscal disparities because of historical patterns of public employment. ${ }^{24}$ Basing the balancing factor on the previous SDO and INPRES meant that local governments that used to receive big transfers continued to receive them. ${ }^{25}$

Some empirical evidence on the equalization impact of transfers in 2002 is presented in Table 8.10 for provinces and Table 8.11 for districts/municipalities. These tables show the dispersion of revenues per capita (coefficient of variation and range between maximum and minimum values) for own revenues, the two main categories of shared revenues, and the DAU. The tables also show the dispersion for different cumulative arrangements of revenue sources. We also made these calculations for 2001 , with very similar results.

In the case of the provinces, general revenue sharing and sharing of natural resources show more dispersion than own revenues, but the cumulative distribution of total revenues per capita after the DAU is added has a significantly lower dispersion. The coefficient of variation falls from 1.90 before the DAU to 0.90 after the DAU in $2002 .{ }^{26}$ Similar results hold for districts/municipalities. The main contrasts are that the sharing in natural resource revenues appears to be much more unequalizing at local level and that the DAU distributions have a stronger equalizing effect. For example, in 2002 the coefficient of variation for revenues per capita before the DAU is 2.58 , and drops to 1.04 after the DAU.

These results provide general evidence that the DAU has equalizing effects at provincial and district/municipality levels. However, even after the DAU, the coefficients of variation remain high, always with a value over one. The very large differences between maximum and minimum values of revenues per capita dramatize the fact that DAU is still not effective in reducing fiscal disparities to acceptable levels.

An additional way to examine the equalization performance of the DAU is to study whether it lives up to its promise of equalizing fiscal capacity and expenditure needs. With this objective in mind, we ran a series of regressions explaining DAU distributions at provincial level for 2001 and 2002 and at district/municipality level also for 2001 and 2002. Besides using the entire DAU allocation as the dependent variable, we also added two other dependent variables by breaking up the DAU allocation into the 'balancing fund amount' and the 'formula amount.' For explanatory variables, we selected the variable 'gross regional product per capita' (GDRPCAP) as a measure of fiscal capacity, and we also used as a control variable 'tax effort.' For explanatory variables on the expenditure need side, we selected some of the 
Table 8.10 Equalizing impact of the DAU for provinces, 2002 (in thousands of rupiahs)

\begin{tabular}{|c|c|c|c|c|c|}
\hline Variable & Mean & $\begin{array}{l}\text { Standard } \\
\text { deviation }\end{array}$ & $\begin{array}{l}\text { Coefficient } \\
\text { of variation }\end{array}$ & Maximum & Minimum \\
\hline LOR 1999 (Local own revenue) & 23.73 & 38.56 & 1.62 & 201.90 & 5.22 \\
\hline TS 2001 (Tax sharing) & 17.42 & 51.81 & 2.97 & 289.01 & 3.07 \\
\hline NRS 2001 (Natural resource sharing) & 26.49 & 76.25 & 2.88 & 376.82 & 0.01 \\
\hline DAU 2002 (General allocation fund) & 72.31 & 50.88 & 0.70 & 185.21 & 11.10 \\
\hline $\mathrm{LOR}+\mathrm{TS}$ & 37.99 & 87.26 & 2.30 & 490.91 & 3.14 \\
\hline LOR+NRS & 45.29 & 84.90 & 1.87 & 409.91 & 0.02 \\
\hline LOR+DAU 2002 & 92.88 & 59.10 & 0.64 & 265.83 & 19.37 \\
\hline LOR+TS+DAU 2002 & 110.30 & 97.89 & 0.89 & 554.83 & 27.57 \\
\hline LOR+NRS+DAU 2002 & 117.60 & 89.41 & 0.76 & 448.94 & 19.40 \\
\hline $\mathrm{LOR}+\mathrm{TS}+\mathrm{NRS}$ & 62.71 & 118.85 & 1.90 & 502.27 & 3.91 \\
\hline LOR+TS+NRS+DAU 2002 & 135.02 & 121.02 & 0.90 & 566.20 & 27.60 \\
\hline
\end{tabular}

Source: Authors' calculations. See Appendix 8.2 for a full definition of all variables. 
Table 8.11 Equalizing impact of the DAU for districts/municipalities, 2002 (thousands of rupiahs)

\begin{tabular}{lrrrrr}
\hline Variable & Mean & $\begin{array}{c}\text { Standard } \\
\text { deviation }\end{array}$ & $\begin{array}{l}\text { Coefficient } \\
\text { of variation }\end{array}$ & Maximum & Minimum \\
\hline LOR 1999 (Local own revenue) & 22.42 & 50.31 & 2.24 & 855.25 & 0.30 \\
TS 2001 (Tax sharing) & 28.48 & 37.26 & 1.31 & 265.36 & 4.34 \\
NRS 2001 (Natural resource sharing) & 128.64 & 431.37 & 3.35 & 4609.57 & 0.27 \\
DAU 2002 (General allocation fund) & 522.55 & 393.35 & 0.75 & 3376.53 & 110.76 \\
LOR+TS & 50.89 & 67.88 & 1.33 & 924.48 & 6.21 \\
LOR+NRS & 151.06 & 435.98 & 2.89 & 4630.49 & 5.44 \\
LOR+DAU 2002 & 544.96 & 398.66 & 0.73 & 3395.64 & 128.81 \\
LOR+TS+DAU 2002 & 573.44 & 422.14 & 0.74 & 3504.98 & 159.92 \\
LOR+NRS+DAU 2002 & 673.61 & 699.13 & 1.04 & 6797.27 & 129.08 \\
LOR+TS+NRS & 179.54 & 462.33 & 2.58 & 4874.49 & 11.07 \\
LOR+TS+NRS+DAU 2002 & 702.08 & 727.77 & 1.04 & 7041.28 & 160.19 \\
\hline
\end{tabular}

Source: Authors' calculations. See Appendix 8.2 for a full definition of all variables. 
variables used in the DAU formula, such as the construction price index and the percent living in poverty; we also selected other variables that are reflective of need and are not strictly included in the DAU formula, such as percent of the population of retirement age, percent of population younger than working age, and population density. We report only the results for 2002 , in Table 8.12 for provinces and Table 8.13 for districts/municipalities.

The regression results show that the DAU allocations generally do not equalize fiscal capacity. In fact, DAU allocations per capita tend to increase with gross regional product per capita, so that richer jurisdictions get higher allocations. This result tends to occur largely because of the impact of the 'balancing fund' ${ }^{27}$ On the expenditure need side, the regression results show that typically the DAU tends to increase with poverty and the construction price index, as expected from the role these variables play in the DAU formula. However, the effects of these variables in the DAU allocations per capita are often diluted, or not statistically significant. Importantly, we find that the 'balancing fund' component of the DAU not only increases with income, but that it also explicitly penalizes those jurisdictions with higher expenditure needs (holding income constant). This is manifested by the negative and statistically significant regression coefficients for the "balancing

Table 8.12 Regression analysis of the DAU for provinces, 2002 (per capita in thousands of $R p$ )

\begin{tabular}{|c|c|c|c|c|}
\hline $\begin{array}{l}\text { Independent } \\
\text { variable }\end{array}$ & $\begin{array}{c}\text { DAU } \\
\text { transfers }\end{array}$ & $\begin{array}{c}\text { Regional } \\
\text { expenditure }\end{array}$ & $\begin{array}{l}\text { Balancing } \\
\text { fund per } \\
\text { capita }\end{array}$ & $\begin{array}{c}\text { DAU } \\
\text { formula } \\
\text { per capita }\end{array}$ \\
\hline Intercept & -8.6 & -77.9 & 18.07 & -26.68 \\
\hline $\begin{array}{r}\text { GRDP } 1999 \\
\text { per capita }\end{array}$ & -0.001495 & $0.007186^{*}$ & 0.0009881 & -0.002483 \\
\hline Const index & 0.1888 & 0.613 & -0.1415 & 0.3303 \\
\hline Poor & $1.6872 *$ & $2.882 *$ & $0.5761^{*}$ & 1.1111 \\
\hline Older & -5.841 & -16.36 & -1.925 & -3.916 \\
\hline Younger & 1.437 & 0.832 & 0.3186 & 1.1185 \\
\hline Density & 0.004222 & -0.008308 & 0.001386 & 0.002836 \\
\hline Tax effort & -21.03 & $159.54 *$ & 19.43 & -40.47 \\
\hline $\mathrm{R}^{2}$ & 0.310 & 0.473 & 0.319 & 0.426 \\
\hline
\end{tabular}

Notes:

* Indicates statistical significance at the 10 percent level; ** Indicates statistical significance at the 1 percent level.

Older: Percentage of the populations older than working age; Poor: Percentage of the population in poverty; Younger: Percentage of the population younger than working age. 
Table 8.13 Regression analysis of the DAU for districts/municipalities, 2002 (per capita in thousands of Rp)

\begin{tabular}{lcccc}
\hline $\begin{array}{l}\text { Independent } \\
\text { variable }\end{array}$ & $\begin{array}{c}\text { DAU } \\
\text { transfers }\end{array}$ & $\begin{array}{c}\text { Regional } \\
\text { expenditure }\end{array}$ & $\begin{array}{c}\text { Balancing } \\
\text { fund per } \\
\text { capita }\end{array}$ & $\begin{array}{c}\text { DAU } \\
\text { formula } \\
\text { per capita }\end{array}$ \\
\hline $\begin{array}{l}\text { Intercept } \\
\text { GRDP 1999 }\end{array}$ & $-837.5^{* *}$ & $-477.2^{* *}$ & 52.9 & $-890.4^{* *}$ \\
$\quad$ per capita & $0.003749^{*}$ & $0.004521^{* *}$ & $0.005085^{* *}$ & -0.001335 \\
Const index & $11.352^{* *}$ & $7.5469^{* *}$ & $3.4472^{* *}$ & $7.9051^{* *}$ \\
Poor & -1.752 & $-2.130^{*}$ & $-2.2181^{* *}$ & 0.4656 \\
Older & -1.30 & -3.804 & -6.277 & 4.981 \\
Younger & $-5.104^{*}$ & -1.523 & $-5.717^{* *}$ & 0.614 \\
Density & -0.016025 & $-0.018058^{*}$ & $-0.012169^{*}$ & -0.003856 \\
Tax effort & 26.47 & 26.06 & 6.9 & 19.48 \\
$\mathrm{R}^{2}$ & 0.326 & 0.275 & 0.210 & 0.387 \\
\hline
\end{tabular}

\section{Notes:}

* Indicates statistical significance at the 10 percent level; ** indicates statistical significance at the 1 percent level.

Older: Percentage of the populations older than working age; Poor: Percentage of the population in poverty; Younger: Percentage of the population younger than working age.

factor' on poverty and the percent of population with higher public expenditure needs, such as the young and the old.

In summary, the regression results provide evidence that the implementation of the DAU has been pushing for conflicting objectives. The 'formula amount' pushes for equalization, but the 'balancing factor' undermines equalization via its pursuit of addressing vertical imbalances. It is quite unlikely that this is something that the policymakers in the executive and the Parliament wanted, and it highlights the need to further reform Indonesia's system of transfers. ${ }^{28}$

\section{CONCLUSIONS: THE WAY FORWARD}

Indonesia has made remarkable progress over the last two years in putting together an efficient and effective system of intergovernmental transfers. In this very short period Indonesia has achieved what has taken other countries a decade or longer to achieve. Progress has been most evident in the design, as opposed to the implementation, of the DAU system of equalization transfers. However, problems remain in a number of areas, including the DAU. 
The most fundamental problem is that the GOI has relied on the DAU to pursue too many objectives. Although current legislation proclaims the essence of the DAU as an equalization grant, in practice the GOI has used the DAU to pursue other objectives, the most significant of which are closing the vertical balance between the central and sub-national governments and redressing perceived historical injustices in the allocation of revenues from natural resources. More recently, there have been noises in government circles about also using the DAU to ensure that certain national expenditure priorities are safeguarded under decentralization.

So far, the outcome of pursuing these many policy objectives with one policy instrument, the DAU, has been muddled or confused performance. The equalization results the DAU achieves through its 'formula component' are to a large extent undone by the implementation of its 'balancing factor component.' The GOI needs to develop within the system of transfers new tools to address important policy objectives other than equalization.

The recent reforms introduced revenue sharing as an almost new instrument of sub-national finance in Indonesia. However, revenue sharing plays a significant role for only a minority of sub-national governments, and those that benefit from revenue sharing seem to be powerless in predicting how much they are going to receive in funds during the fiscal year. The other instrument of sub-national finance introduced by the recent reforms, the conditional matching grants, has not been used at all.

These considerations lead us to make several general recommendations, as well as some specific suggestions for the DAU and the DAK.

Regarding general recommendations, we believe the future reform of the system of transfers should follow three fundamental thrusts. First, the GOI should expand revenue autonomy at sub-national level as the best way to address vertical imbalances. Politically, it will be hard to retrench from the current level of revenue sharing, especially in the case of natural resource revenues. However, little can be gained from expanding revenue sharing to address vertical imbalances. Providing provinces and districts/municipalities with more significant discretion over tax rates can achieve the same results with the added benefits of increased efficiency and accountability at subnational level. Central government needs to evaluate the applicability of the 'piggybacking' system for personal income tax, but also of other taxes as a way to provide revenue autonomy at sub-national level. Property tax should be fully assigned at local level.

Second, the DAU must be used exclusively in the pursuit of the equalization objective. This will mean that addressing the issue of perceived historical injustices in the sharing of revenues from natural resources will have to be pursued though revenue sharing as is now the case, or even through special transfers. Similarly, the general funding or vertical imbalance issue, now 
pursued with the 'balancing factor' within the DAU, needs to be addressed through more tax autonomy, more revenue sharing, or additional transfers. The DAU structure should be updated with the goal of improving on its equalization performance. The GOI will need to define explicitly its equalization target and to determine whether zero or even negative allocations will be allowed.

Third, there is widespread concern at central government level that local governments might not pay enough attention to national priorities such as basic education and primary health, poverty alleviation, or infrastructure provision. The GOI needs to develop a system of conditional grants under the legal umbrella of the DAK to pursue specific policy objectives regarding infrastructure or particular central government programs. Because of the importance of the health and education sectors in national priorities and the fact that these are now the responsibilities of local governments, the GOI could develop a system of per capita conditional grants that would ensure minimum expenditure standards at local level in these sectors. Funding for per capita conditional grants in health and education could come in part from the funds now spent on the balancing factor of the DAU. These conditional grants would provide help with a 'hold harmless' objective but would switch funding from budget inputs (e.g. public employees) to budget outputs (e.g. number of children educated and population at risk). The funding for conditional grants for infrastructure and other areas could come in part from the still largely deconcentrated funds now controlled by the line ministries in Jakarta.

It is important for the new set of reforms in the transfer system to be part of the comprehensive view of where the entire system of intergovernmental fiscal relations is going, and not just the system of transfers. But for these reforms to fit together well, it is still necessary for the GOI to produce an overall strategy, or 'white paper,' for reform.

Central government also needs to examine the current administrative organization. In particular, should the reformed equalization transfers and the new conditional grants flow directly from central government to local governments, or should they go through the provinces as the intermediate level of government? This decision should be congruent with the choice made on the overall approach to organizing intergovernmental fiscal relations.

The GOI should further consider the need for formalizing the management of the system of DAU and DAK transfers. There is a need to collect better statistics and to improve the existing ones. For the calculation of the DAU in 2002, for example, there are some variables still using 1999 data. Ideally, the data used for calculating the DAU should be for two years at most prior to the year of DAU (e.g. for DAU 2002, all data should be 2000 data). In addition, the reliability and consistency of data essential to the DAU are sometimes 
doubtful, especially for population and area; the information on the construction price index is also of questionable reliability. There is also a need to update the equalization formula, introducing changes in the mechanism to keep within its objectives, and to maintain a dialog with sub-national governments and other stakeholders. Several government agencies currently are in charge of administering the DAU. One possibility is whether to imitate other countries such as Australia and India and to create a 'grants commission,' a semi-autonomous institution at central government level that is exclusively charged with the administration and upkeep of the transfer system. The advantage of a 'grants commission' is its greater impartiality and objectivity in administering the equalization grant system.

As for more specific suggestions regarding the DAU, the current practice of distributing the DAU pool of funds as fixed in the budget is a desirable approach because regional governments have more certainty about planning and executing their budgets once the central budget is approved. The actual rule of 25 percent of net domestic revenues can and should be changed in the overhaul of the system of transfers, but it is desirable that the new percentage should stay stable for a period of several years. Overall funding for the DAU needs to be decided in the wider context of intergovernmental fiscal relations and national priorities. How much of the available national resources should be dedicated to equalizing sub-national fiscal disparities is a political decision that requires the direct involvement of Parliament and the government. However, in order to reach the right level of funding, the DAU funding rule needs to be openly discussed and the country priorities reflected in it.

Equalization transfers in Indonesia are correctly conceived of as unconditional (or general funding) grants, with their final use left to the discretion of local governments. Pressure to impose conditionality on the use of those funds must be resisted. Conditional grants should be used for the pursuit of other objectives.

There is a need to remove the negative incentives that remain in the form of using the wage bill as the basis of the distribution of finance for the "hold harmless' funds.

The introduction of explicit public service standards for the computation of expenditure needs may bring more problems than benefits. Clearly, expenditure norms defined by the Ministry of Finance or any other agency cannot in the present economic circumstances be anywhere near the level that sub-national governments would consider adequate; otherwise there would be a very significant budget deficit at sub-national or central levels. Thus the use of explicit standards may contribute to the feelings of insensitivity and injustice toward sub-national governments. The current approach now used in the DAU of using an index to approximate needs is used in many other countries. $^{29}$ 
There is a need for better data and improved measurements of fiscal capacity at provincial and local levels. Natural resources revenue sharing has to be considered 100 percent revenue to local governments and not just 75 percent as is now the case. Central government must not accept local government demands to switch to actual or collected own revenues in the measurement of fiscal capacity, as agreeing to this will certainly create negative incentives for revenue mobilization by local governments. Instead, there is a need to develop better estimation methods of potential local own revenue.

Finally, we have several specific suggestions for the DAK. First, if conditional grants for education and health are introduced, they should be computed on a per student and per inhabitant basis, respectively. ${ }^{30}$ This offers the advantages of the grants being inherently equalizing, of them providing local authorities with budgetary autonomy in terms of expenditure priorities (within education and health), and of the grants providing the most efficient method of service delivery. ${ }^{31}$ These grants may imply, among other things, changes in revenue sharing and quite likely a reduction in the pool of funds dedicated to equalization under the DAU. Second, as is the case for the DAU, the design of conditional transfers must take into account the potential strategic behavior of sub-national governments and the incentive signals provided to them in the structure of capital grants. A good dose of realism will also be necessary. It will typically be desirable that DAK grants satisfy the requirement of 'additionality,' so that capital grants are not a substitute for capital expenditure that sub-national governments would otherwise have undertaken. For this reason, DAK transfers should keep the co-financing (or matching) requirements now in the law. Third, it will be more efficient and transparent to allocate conditional grant funds by using objective formulas. When a formula approach is not feasible, the allocation of funds and the selection process for the grants should still be made according to explicitly legislated criteria.

\section{NOTES}

The authors are very grateful to James Alm for comments and Rofiq for computational assistance.

1. Revenue sharing on a derivation basis means that central government shares revenues with the sub-national governments where the revenues have been collected or derived.

2. See Silver, Azis, and Schroeder (2001) for an evaluation of the SDO and INPRES systems.

3. Of course, the common accusation outside Jakarta has been that central government has practiced de facto asymmetric decentralization policies by benefiting Jakarta and more generally Java at the cost of the other provinces. This is a complex issue. Before 1999, there was no revenue sharing from natural resources, but rural provinces such as Papua seem to have been favored under the INPRES system.

4. In addition, Papua gets a special grant equal to 2 percent of the DAU transfer. Another important asymmetric benefit for these two provinces is that the additional revenue sharing 
provided in the special autonomy laws is not to be taken into account in the computation of fiscal capacity in the DAU formula. This benefit is on top of the general benefit that all natural resource producing provinces and local governments receive because the measurement of fiscal capacity in the DAU formula in 2002 only recognizes 75 percent of shared revenues, when all other shared revenues are recognized at 100 percent.

5. The current practice is to apportion PIT among jurisdictions by 'place of work' rather than 'place of residence.' This can lead to unfair apportionment of revenues among jurisdictions in large metropolitan areas where many individuals reside in one jurisdiction where they consume most of their public services, but have their place of work in different jurisdictions.

6. In 2001 the lump sum was determined in a residual fashion, as the moneys left after the funds distributed through the formula and the balancing amount. The latter is defined later.

7. The wage bill for each jurisdiction was computed as the money spent for that purpose in September 2001 times.12 months.

8. This clearly could be the case if public employees per capita were not evenly distributed across the territory. Historically, better off regions had more services and public bureaucrats.

9. Recall that revenue sharing from natural resources is not fully taken into account in the derivation of fiscal capacity of local governments.

10. Law No. $25 / 1999$ seems to be referring here to the financing of physical capital investment. However, there is also the possibility of interpreting the DAK as a system of conditional grants for current and capital expenditures.

11. This is a much broader term, which would seem to allow all sorts of conditional grants for defined sectoral objectives in health, education, and so on.

12. This matching rule does not apply to reforestation funds.

13. The reforestation fees are distributed 40 percent to the producing regions while the rest is kept by central government for reforestation activities all over the country, especially in non-producing regions.

14. All four factors (population, land area, poverty, and geographical conditions as proxied by the construction price index) are mentioned in Law No. 25/1999. A general interpretation has been that the reference in Law No. 25/1999 does not mean that these variables need to be entered the way they were entered in 2001 , or that other variables could not be entered. As for weights, the equal weights in 2001 were widely believed to be off the mark. For example, population seemed to be significantly under-weighted vis-à-vis the other variables. To arrive at the right weights, it is necessary to remember that the expenditure needs index serves as a substitute for a bottom-up approach that would estimate expenditure needs on the basis of the costs of delivering a standard basket of public services across local governments. This bottom-up approach would be more likely to reflect disparities in expenditure needs than a simple index. However, the bottom-up approach is more complex and is fraught with political complications.

15. Another possibility would be to introduce negative transfers or compulsory extractions from these local governments as payments to the pool of funds to be distributed through the equalization mechanism. This is essentially the approach adopted by countries that have horizontally funded (also known as 'fraternal') equalization grant systems. This approach would appear to deviate significantly from the spirit of the current DAU system.

16. The measure may be institutionally biased against sub-national governments since typically those governments are not as free as the central government to run budget deficits and to borrow to finance their expenditures.

17. The question of revenue adequacy at different levels of government must be answered politically. For any assignment of expenditure responsibilities among different levels of government, the revenue sources and other funding provided to sub-national governments is a question of establishing clear national priorities. How much of the national resources does the country wish to spend on education, health, and other sub-national expenditure responsibilities vis-à-vis other important services, such as national defense, assigned at the central level? These decisions about spending priorities are likely to change over time, 
and they are most conveniently made within the context of a medium-term expenditure framework. Revenue adequacy and vertical balance should logically be interpreted within the context of the overall constraint on public sector resources. It is always helpful to have a national dialog on what constitutes 'adequate resources,' with participation of all stakeholders. Although perfect consensus is unlikely to be reached, the dialog can protect sub-national governments from central government using decentralization as a way to solve its own fiscal shortcomings, and can also be a way to facilitate the role of the central authorities by making sub-national governments more aware of existing fiscal constraints.

18. Matching arrangements help to obtain 'additionality' or 'maintenance-of-effort' in subnational expenditures, and tend to increase ownership of projects at local level.

19. However, often the fundamental question remains of why central authorities would have better information than sub-national governments regarding the right input mix in the production of sub-national public services.

20. Clearly, there will not be good education services, for example, if there are no funds for books and basic supplies, regardless of the quality and newness of school buildings.

21. Unfortunately, this is fraught with difficulties in measuring the quantity and quality and because of the need to avoid rewarding sub-national governments that have made clearly voluntary decisions to spend less on capital infrastructure and more on other types of expenditures. Capital grants should not be a substitute for prudent borrowing policies by sub-national governments.

22. The most important limitations on local budget autonomy are inabilities to reduce personnel and to set wages.

23. The 2001 contingency fund was budgeted at Rp 6.2 trillion of which Rp 2.8 trillion was disbursed. In 2002 central government used the budgeted contingency fund of Rp 2.1 trillion to fund part of the 'hold harmless' funds mandated by Parliament.

24. See Hofman et al. (2002).

25. Despite the inertia introduced in the system by the balancing factor, it is interesting to note that the new DAU system is more equalizing than the old SDO and INPRES system. See Lewis (2001).

26. For 2001, the coefficient of variation falls from 1.90 before the DAU to 1.18 after the DAU.

27. It is interesting that the 'DAU formula amount' for 2001 was positively and statistically significant related to gross regional product per capita at district/municipality level, but that this relationship did not hold for 2002 .

28. Our regression results are generally consistent with those obtained by Lewis (2001) and Hofman et al. (2002).

29. See Alm and Martinez-Vazquez (2002) for a discussion of expenditure norms.

30. The per capita basis could be modified, if needed, by some adjustment coefficient to reflect different costs of provision or needs.

31. It must be made clear that the conditional grants should not be made for economic categories of expenditure, such as wages and salaries. This would eliminate any of the advantages of a decentralized delivery and implementation system and the full centralization of those services would produce the same results. Naturally, for local governments to be able to increase efficiency in the delivery of services, it would also be necessary to reduce, if not eliminate, central government norms and mandates that interfere with their choices.

\section{REFERENCES}

Alm, James, Robert Aten and Roy Bahl (2001). 'Can Indonesia Decentralize Successfully? Plans, Problems, and Prospects'. Bulletin of Indonesian Economic Studies, 37 (1), 83-102. 
Alm, James and Jorge Martinez-Vazquez (2002), 'On the Use of Budget Norms as a Tool for Fiscal Management'. Public Finance and Management, 2 (3), 387-435.

Hofman, Bert, Kadjatmiko and Kai Kaiser (2002). 'Fiscal Equalization in Indonesia's "Big Bang” Decentralization.' Unpublished Manuscript. Jakarta: World Bank and Ministry of Finance.

Lewis, Blane D. (2001). 'The New Indonesian Equalization Transfer'. Bulletin of Indonesian Economic Studies, 37 (3), 325-43.

Lewis, Blane D. (2002). 'Revenue-sharing and Grant-making in Indonesia: The First Two Years of Fiscal Decentralization'. In Paul Smoke (ed.), Intergovernmental Transfers in Asia. Manila: Asian Development Bank.

Martinez-Vazquez, Jorge (2001). 'An Evaluation of Indonesia's DAU Equalization Grant'. IRIS/USAID, Jakarta (February).

Silver, Christopher, Iwan J. Azis and Larry Schroeder (2001). 'Intergovernmental Transfers and Decentralization in Indonesia'. Bulletin of Indonesian Economic Studies, 37 (3), 345-62. 


\section{APPENDIX 8.1 THE 2002 AND 2001 DAU FORMULAE}

\section{A. 2002 General Allocation Fund (DAU) Formula}

I. Fiscal Gap = Fiscal (Expenditure) Needs - Fiscal Capacity

II. Fiscal Capacity $=$ LORadj $+(\mathrm{PT}+\mathrm{LTF}+\mathrm{PIT}+0.75 * \mathrm{NRS})$

LORadj: Local Own Revenue Adjustment (or Predicted) $=\mathrm{a}+\mathrm{b}^{*}$ GRDP Services

PT: $\quad$ Property Tax Revenue Sharing

LTF: $\quad$ Land Transfer Fee Revenue Sharing

PIT: $\quad$ Personal Income Tax Revenue Sharing

NRS: $\quad$ Natural Resources Revenue Sharing

III. Fiscal Needs $=$ ALE $(0.4 \mathrm{PI}+0.1 \mathrm{AI}+0.1 \mathrm{RPI}+0.4 \mathrm{CI})$

$\begin{array}{ll}\text { ALE: } & \text { Average Local Expenditure } \\ \text { PI: } & \text { Population Index } \\ \text { AI: } & \text { Area Index } \\ \text { RPI: } & \text { Relative Poverty Index } \\ \text { CI: } & \text { Construction Index }\end{array}$

$$
V \cdot D A U_{i}=\mathrm{AM}+\left(\mathrm{LDW} * \mathrm{DAU}_{\mathrm{n}}\right)
$$

Local DAU Weight $($ LDW $)=$ Local Fiscal Gap/National Fiscal Gap

$\mathrm{DAU}_{\mathrm{i}}$ : $\quad$ DAU for each province or district/municipality

$\mathrm{DAU}_{\mathrm{n}}$ : DAU total, for all province or district/municipality

AM: $\quad$ Minimum Allocation $=\mathrm{LS}+\left(\mathrm{a}^{*} \mathrm{CSS}\right)$

LS: Lump sum equal for each province or district/municipality

a*CSS: Proportion of Civil Servant Salary in 2001

\section{B. 2001 General Allocation Fund (DAU) Formula}

\section{Fiscal Needs}

Fiscal Needs $=$ Average Local Expenditures $* 1 / 4($ Population Index + Area Index + Construction Price Index + Poverty Index) 
Fiscal Needs Variables:

a. Average Local Expenditures

Average Local Expenditures $=($ Total Local Expenditures + Deconcentrated Funds)/Number of Local Governments

b. Population Index

Population Index = Local Population/Average Local Population

c. Area Index

Area Index $=$ Local Area/Average Local Area

d. Construction Price Index

Construction Price Index $=$ Local Construction Price Index $/ 100$

e. Poverty Index

Poverty Index $=$ Number of Local Poor People/Average Local Poor People

\section{Fiscal Capacity}

Fiscal Capacity $=$ Average Local Revenue $* 1 / 3$ (Industrial Index + Natural Resources Index + Human Resources Index)

Fiscal Capacity Variables:

a. Average Local Revenue

Average Local Revenue = (Local Own Revenue + Tax Revenue Sharing $) /$ Number of Local Governments

b. Natural Resources Index

Natural Resources Index $=($ GRDP of Natural Resources/GRDP $)$ /

(GDP of Natural Resources/GDP) 
c. Industrial Index

Industrial Index $=($ GRDP of Non Primary Sectors/GRDP $) /($ GDP of Non Primary Sectors/GDP)

d. Human Resources Index

Human Resources Index = (Local Labor Force/Local Population)/(National Labor Force/National Population)

\section{General Allocation Fund (GAF)}

GAF of a Local Government $=$ Fiscal $($ Expenditure) Needs - Fiscal Capacity Local GAF Weight = GAF of a Local Government/GAF of All Local Governments

GAF Distributed for a District/Muncipality $=0.9 * 0.25 *$ Total Domestic Revenue in National Budget * Local GAF Weight

GAF Distributed for a Province $=0.1 * 0.25 *$ Total Domestic Revenue in National Budget * Local GAF Weight 


\section{APPENDIX 8.2 TABLE OF VARIABLE DEFINITIONS AND UNITS OF MEASUREMENT}

\begin{tabular}{|c|c|c|}
\hline Variable & Definition & Units of measurement \\
\hline POP & Number of people & Thousands of people \\
\hline POOR & Number of people in poverty & Thousands of people \\
\hline POVGAP & Poverty gap & Thousands of people \\
\hline LABOR & $\begin{array}{l}\text { Number of people in working } \\
\text { age (age 15-59) }\end{array}$ & Thousands of people \\
\hline SCHOOL AGE & Number of people in school & Thousands people \\
\hline OLDER & $\begin{array}{l}\text { Number of people older than } \\
\text { working age }(>59)\end{array}$ & Thousands people \\
\hline YOUNGER & $\begin{array}{l}\text { Number of people younger } \\
\text { than working age }(<15)\end{array}$ & Thousands people \\
\hline PCT POOR & $\begin{array}{l}\text { Percentage poor people of } \\
\text { population }\end{array}$ & Percent \\
\hline PCT LABOR & $\begin{array}{l}\text { Percentage working people of } \\
\text { population }\end{array}$ & Percent \\
\hline PCT SCHOOL AGE & $\begin{array}{l}\text { Percentage school age people } \\
\text { of population }\end{array}$ & Percent \\
\hline PCT OLD & $\begin{array}{l}\text { Percentage older people of } \\
\text { population }\end{array}$ & Percent \\
\hline PCT YOUNG & $\begin{array}{l}\text { Percentage younger people of } \\
\text { population }\end{array}$ & Percent \\
\hline AREA (KM) & Land area of local authority & $\mathrm{km}^{2}$ \\
\hline DENSITY (PER KM) & Population/Area & People/km² \\
\hline CONST INDEX & Construction price index & - \\
\hline GRDP 1999 PER CAP & GRDP/Population & Thousands of rupiahs \\
\hline TAX EFFORT (1999) & $\begin{array}{l}\text { (Local Tax+User Charges)/ } \\
\text { Population }\end{array}$ & Thousands of rupiahs \\
\hline $\begin{array}{l}\text { TOTAL COLLECTION } \\
1999 \text { PER CAPITA }\end{array}$ & $\begin{array}{l}\text { Local Own Revenue/ } \\
\text { Population }\end{array}$ & Thousands of rupiahs \\
\hline $\begin{array}{l}\text { REVENUE SHARE PER } \\
\text { CAPITA (2001) }\end{array}$ & $\begin{array}{l}\text { (Tax Sharing+Natural Share)/ } \\
\text { Population }\end{array}$ & Thousands of rupiahs \\
\hline
\end{tabular}




\begin{tabular}{|c|c|c|}
\hline Variable & Definition & Units of measurement \\
\hline DAU 2001 PER CAPITA & DAU 2001/Population & Thousands of rupiahs \\
\hline $\begin{array}{l}\text { AFTER DAU } 2001 \text { PER } \\
\text { CAPITA }\end{array}$ & $\begin{array}{l}\text { (Local Own+DAU 2001)/ } \\
\text { Population }\end{array}$ & Thousands of rupiahs \\
\hline $\begin{array}{l}\text { AFTER ALL TRANSFER } \\
2001 \text { PER CAPITA }\end{array}$ & $\begin{array}{l}\text { (Local Own+DAU 2001+ } \\
\text { Revenue Share)/Population }\end{array}$ & Thousands of rupiahs \\
\hline $\begin{array}{l}\text { REGIONAL REVENUE } \\
2001 \text { PER CAPITA }\end{array}$ & $\begin{array}{l}\text { (Local Own+DAU } 2001+ \\
\text { Revenue Share+Contingency } \\
\text { Fund)/Population }\end{array}$ & Thousands of rupiahs \\
\hline $\begin{array}{l}\text { DAU } 2001 \text { (PCT OF } \\
\text { EXPENDITURE) }\end{array}$ & DAU 2001/Expenditure & Percent \\
\hline DAU 2002 PER CAPITA & DAU 2002/Population & Thousands of rupiahs \\
\hline $\begin{array}{l}\text { AFTER DAU } 2002 \text { PER } \\
\text { CAPITA }\end{array}$ & $\begin{array}{l}\text { (Local Own+DAU 2002)/ } \\
\text { Population }\end{array}$ & Thousands of rupiahs \\
\hline $\begin{array}{l}\text { AFTER ALL TRANSFER } \\
2002 \text { PER CAPITA }\end{array}$ & $\begin{array}{l}\text { (Local Own+DAU } 2002+ \\
\text { Revenue Share)/Population }\end{array}$ & Thousands of rupiahs \\
\hline $\begin{array}{l}\text { REGIONAL REVENUE } \\
2002 \text { PER CAPITA }\end{array}$ & $\begin{array}{l}\text { (Local Own+DAU } 2002+ \\
\text { Revenue Share+Contingency } \\
\text { Fund)/Population }\end{array}$ & Thousands of rupiahs \\
\hline $\begin{array}{l}\text { DAU } 2002 \text { (PCT OF } \\
\text { EXPENDITURE) }\end{array}$ & DAU 2002/Expenditure & Percent \\
\hline $\begin{array}{l}\text { EXPENDITURES } 2001 \\
\text { PER CAPITA }\end{array}$ & $\begin{array}{l}\text { Expenditure FY } 1999 \text { (with } \\
\text { adjustment)/Population }\end{array}$ & Thousands of rupiahs \\
\hline TRANSFERS & Dau 2001 or DAU 2002 & Billions of rupiahs \\
\hline REVENUE SHARES & (Tax Sharing + Natural Share) & Billions of rupiahs \\
\hline TOTAL COLLECTION & Local Own Revenue & Billions of rupiahs \\
\hline REGIONAL REVENUE & $\begin{array}{l}\text { (Local Own+DAU + Revenue } \\
\text { Share+Contingency Fund/ } \\
\text { Balancing Fund) }\end{array}$ & Billions of rupiahs \\
\hline AFTER TRANFERS & Local Own Revenue + DAU & Billions of rupiahs \\
\hline AFTER ALL TRANSFERS & $\begin{array}{l}\text { Local Own Revenue + DAU } \\
+ \text { Revenue Share }\end{array}$ & Billions of rupiahs \\
\hline $\begin{array}{l}\text { REGIONAL } \\
\text { EXPENDITURE }\end{array}$ & $\begin{array}{l}\text { Routine Expenditure + } \\
\text { Development Expenditure }\end{array}$ & Billions of rupiahs \\
\hline
\end{tabular}

